\title{
SCIDOC
}

International Journal of Dentistry and Oral Science (IJDOS)

ISSN: 2377-8075

\section{Knowledge, Attitude And Practices (KAP) Survey Of Shade Selection For Indirect Veneers}

Research Article

Immadi Laxmi Sujith Kumar', Sindhu Ramesh ${ }^{2 *}$

${ }^{1}$ Department of Conservative Dentistry and Endodontics, Saveetha Dental College, Saveetha Institute of Medical and Technical Sciences, Saveetha University, Chennai- 600077, India.

${ }^{2}$ Professor, Department of Conservative Dentistry and Endodontics, Saveetha Dental College, Saveetha Institute of Medical and Technical Sciences, Saveetha University, Chennai- 600077, India.

\section{Abstract}

The success of any tooth colored restoration is directly related to the accuracy of chair side shade selection. Patients are currently demanding esthetic replacement that must match their existing dentition, and are more concerned about the shade match of their restorations rather than quality of restoration. Consequently chair side shade selection has become a very important step even for experienced dental practitioners, in the overall treatment of the patient. Both the methods carry merits and demerits one from each other. However, due to relative simplicity and low cost, the visual method is still the most commonly used method. The aim of this KAP survey was to study the level of awareness among the students, general dentists and specialists toward shade selection for indirect veneers. A total of 23 questions containing questionnaires was made and distributed by google forms. A snowball sampling was followed for this study. In this survey, a total of 250 responses have been collected, among the questions that were asked, majority of them told age, gender and appointment timing play a very important role in shade selection. Shade determination is more rapidly evolving toward a more objective standard. The clinical importance of a proper shade selection in esthetic dentistry cannot be overlooked.

Keywords: Shade Selection; Veneers; KAP Survey; Anterior Teeth; Restorations.

\section{Introduction}

The success of any anterior tooth colored restoration is directly related to the accuracy of chair side shade selection [1-3]. Patients are currently demanding esthetic replacement that must match their existing dentition, and are more concerned about the shade match of their restorations rather than quality of the restoration [4-7]. Consequently, chair side shade selection has become a very important step for experienced dental practitioners, in the overall treatment of the patient $[8,9]$. Shade selection can be done by visual and instrumental methods. Both the methods carry merits and demerits over each other. However, due to relative simplicity and low cost, the visual method is still the most commonly used method [10-18].

One of the main concerns in the visual method is its highly subjective nature, different individuals can have different shade presentations for the same object [12, 19-21]. Researchers have explained these differences on the basis of scientific principles and artistic qualities of human vision [13, 22]. Both the factors come into play whenever a shade selection is carried out. To ensure accuracy, various shade selection protocols are important so that visual shade selections can be carried out with accuracy and repeatability [23, 24]. However, those protocols are either not known or are not fully understood by the majority of the dental community including undergraduate students, postgraduate and specialistes $[25,26]$.

Previously our team has a rich experience in working on various research projects across multiple disciplines [27-41]. Now the growing trend in this area motivated us to pursue this project. The aim of the present study was to determine the knowledge,

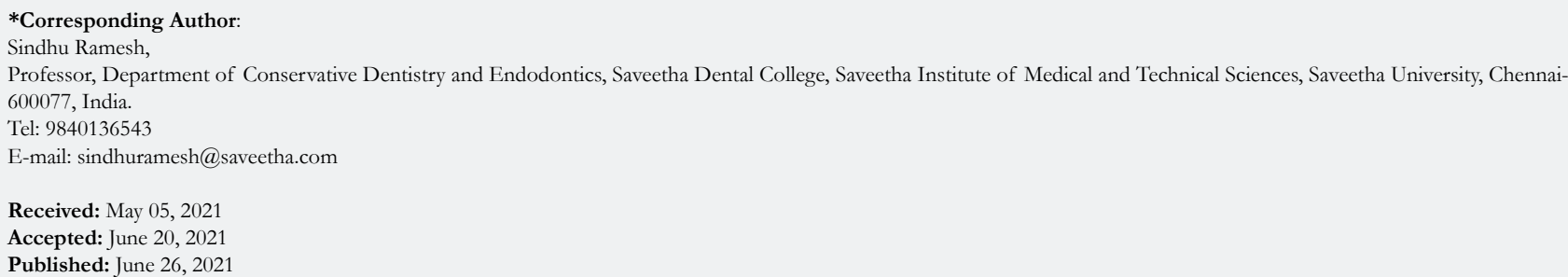

Citation: Immadi Laxmi Sujith Kumar, Sindhu Ramesh. Knowledge, Attitude And Practices (KAP) Survey Of Shade Selection For Indirect Veneers. Int J Dentistry Oral Sci. 2021;8(6):2856-2864. doi: http://dx.doi.org/10.19070/2377-8075-21000557

Copyright: Sindhu Ramesh 2021 . This is an open-access article distributed under the terms of the Creative Commons Attribution License, which permits unrestricted use, distribution and reproduction in any medium, provided the original author and source are credited. 
attitude and practices about the principles and protocols of the shade selection.

\section{Materials And Method}

This cross sectional survey was conducted during April to May 2020 including students and practitioners. Response was obtained from 250 participants. Ethical permission to carry out the study was obtained from Saveetha University Scientific review board. Snowball sampling method was used to distribute the questionnaire among the participants. The questionnaire consisted of 22 questions which included gender, age and specialty. The questionnaire had 22 questions in which 11 questions based on knowledge, 5 based on attitude, 6 questions based on practice were created. 250 responses were assessed and the output was represented in a pie chart for each and every question.

\section{Ethical Approval}

Ethical permission and approval for the project was obtained from the institutional review board of Saveetha Institute Of Medical And Technical Sciences, Chennai, India on date 25/04/2020 [SDC/SIHEC/2020/DIASDATA/0619-0320].

\section{Eligibility Criteria}

Specialists, general practitioners and dental students from all over India.

\section{Data Collection}

This cross sectional survey was conducted during April to May 2020. The questionnaire was shared online via google forms and responses were obtained from 250 participants. The data for 23 questions was compiled and represented in pie charts obtained from the google forms.

\section{Sample Size}

Total number of online questionnaires shared was 280. Out of which 23 did not take up the survey and 7 were incomplete forms which were excluded from the study. Hence, the total number of the participants were 250 .

\section{Results}

We received 250 responses from the participants and among 250 responses, $49.6 \%$ consisted of females and $50.4 \%$ consisted of male. $65.6 \%$ of the participants were under the age group $20-30$ years. Majority of the participants were MDS(78.0\%).(Table 1).

Responses of participants on what is essential during shade selection, Majority of the participants from MDS responded individual observer $(36.80 \%)$, majority of the participants from BDS responded with knowledge $(11.60 \%)$. The association was analysed using Chi square test and was found to be statistically no significant difference. ( $p>0.05$ ) (Table 2 and Figure 1). Responses of participants on what they think plays a major role in shade selection selection, Majority of the participants from MDS responded hue $(38.40 \%)$, majority of the participants from BDS responded with hue(11.60\%). The association was analysed using Chi square test and was found to be statistically no significant difference. ( $p>0.05)$ (Table 3 and Figure 2). Responses of participants on variables affects the perception of color, Majority of the participants from MDS responded tooth, including textures and layers $(28.00 \%)$, majority of the participants from BDS responded tooth, including textures and layers(9.20\%). The association was analysed using Chi square test and was found to be

Table 1. Showing demographic data of participants with number of responses in percentage. Out of which females were $49.6 \%$, the age group of $20-30$ yes were $65.9 \%$ and MDS were $78.0 \%$.

\begin{tabular}{|c|c|c|c|}
\hline $\begin{array}{c}\text { Demographic } \\
\text { variables }\end{array}$ & Categories & No. of respondents & Percentage \% \\
\hline \multirow{2}{*}{ Gender } & Female & 124 & 49.6 \\
\cline { 2 - 4 } & Male & 126 & 50.4 \\
\hline \multirow{2}{*}{ Age (years) } & $20-30$ years & 164 & 65.6 \\
\cline { 2 - 4 } & $31-40$ years & 69 & 27.6 \\
\cline { 2 - 4 } & $41-50$ years & 17 & 6.8 \\
\hline \multirow{2}{*}{ Qualification } & MDS & 195 & 78 \\
\cline { 2 - 4 } & BDS & 55 & 22 \\
\hline
\end{tabular}

Table 2. Shows the distribution of responses of participants on what is essential during shade selection, showing statistically significant between the variables. $(p<0.05)$.

\begin{tabular}{|c|c|c|c|c|c|}
\hline \multirow{2}{*}{$\begin{array}{c}\text { Qualifica- } \\
\text { tion }\end{array}$} & \multicolumn{4}{|c|}{$\begin{array}{c}\text { In your opinion, which of the following is essential dur- } \\
\text { ing shade selection ? }\end{array}$} & \multirow{2}{*}{ P value } \\
\cline { 2 - 5 } & Knowledge & Talent & Skill & Individual observer & \\
\hline MDS & 65 & 15 & 23 & 92 & \multirow{2}{*}{0.014} \\
\hline BDS & 29 & 7 & 5 & 14 & \\
\hline Total & 94 & 22 & 28 & 106 & \\
\hline
\end{tabular}


Figure 1: Bar chart showing the association between qualification of the participants and responses for what is essential during shade selection. $\mathrm{X}$ axis represents essential during shade selection and $\mathrm{Y}$ axis represents the number of responses from participants. The association between MDS(green) and BDS(red) among the different variables was found to be statistically significant with a Chi square value of 10.583 and $p$ value of $0.014(p<0.05)($ Chi square test).

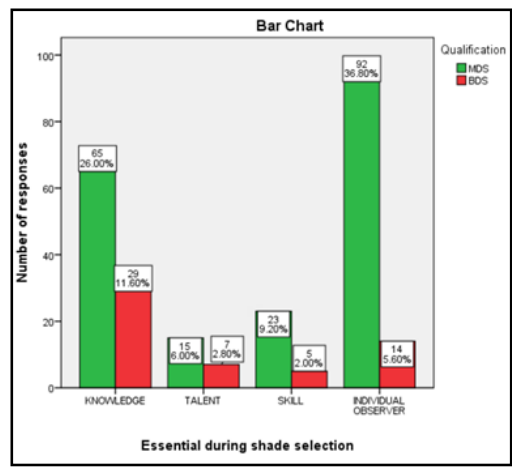

Table 3. Shows the distribution of responses of participants on what they think plays a major role in shade selection selection, showing statistically no significant difference between the variables. $(p>0.05)$.

\begin{tabular}{|c|c|c|c|c|c|}
\hline \multirow{2}{*}{ Qualification } & \multicolumn{4}{|c|}{ Which among these do you think plays a major } & \multirow{3}{*}{ P value in shade selection? } \\
\cline { 2 - 5 } & Hue & Value & Chroma & Translucency & \\
\hline MDS & 96 & 70 & 17 & 12 & \multirow{2}{*}{0.523} \\
\hline BDS & 29 & 22 & 2 & 2 & \\
\hline Total & 125 & 92 & 19 & 14 & \\
\hline
\end{tabular}

Figure 2: Bar chart showing the association between qualification of the participants and responses for what plays a major role in shade selection. $\mathrm{X}$ axis represents a major role in shade selection and the $\mathrm{Y}$ axis represents the number of responses from the participants. The association between MDS(green) and BDS(red) among the different variables was found to be statistically insignificant with a Chi square value of 2.224 and $p$ value of $0.523(p>0.05)$ (Chi square test).

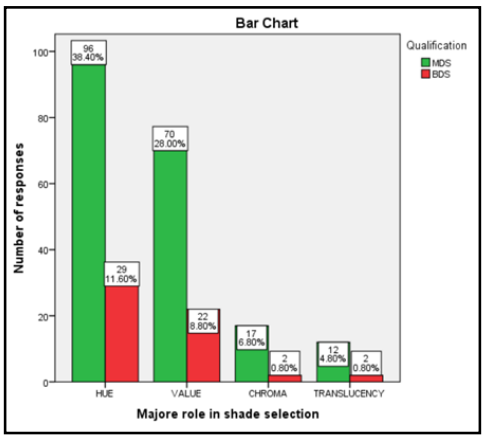

statistically no significant difference. ( $p>0.05$ ) (Table 4 and Figure 3). Responses of participants on the ideal amount of light that is required for shade selection, Majority of the participants from MDS responded 1500 lux (32.00\%), majority of the participants from BDS responded 1500 lux (11.60\%). The association was analysed using Chi square test and was found to be statistically no significant difference. ( $p>0.05$ ) (Table 5 and Figure 4). Responses of participants on the ideal time required for shade selection, Majority of the participants from MDS responded $5-10$ seconds $(40.40 \%)$, majority of the participants from BDS responded 5-10 seconds $(9.20 \%)$. The association was analysed using Chi square test and was found to be statistically no significant difference. ( $p>0.05$ ) (Table 6 and Figure 5). Responses of participants on what they think on shade selection at the beginning of an appointment is better than doing it later, Majority of the participants from MDS responded yes $(70.80 \%)$, majority of the participants from BDS responded yes $(16.80 \%)$. The association was analysed using Chi square test and was found to be statistically significant. $(\mathrm{p}<0.05)$ (Table 7 and Figure 6$)$. Responses of participants on age and gender of the patients play an important role is shade selection, Majority of the participants from MDS responded yes $(73.60 \%)$, majority of the participants from BDS responded yes $(17.60 \%)$. The association was analysed using Chi square test and was found to be statistically significant $(\mathrm{p}<0.05)$ (Table 8 and Figure 7). Responses of participants on Who according to you is more concerned about esthetics, Majority of the participants from MDS responded to younger females $(72.00 \%)$, majority of the participants from BDS responded to young females(18.80\%). The association was analysed using Chi square test and was found to be statistically not significant. $(\mathrm{p}>0.05)$ (Table 9 and Figure 8). Responses of participants on what is the most common complaint patients have regarding anterior teeth restoration, Majority of the participants from MDS responded to esthetic correction( $42.00 \%$ ), majority of the participants from BDS responded to esthetic correction(15.20\%). The association was analysed using Chi square test and was found to be statistically not significant. ( $p>0.05$ ) (Table 10 and Figure 9). Responses of participants on whether they take patients' opinion while do- 
Table 4. Shows the distribution of responses of participants on variable affects the perception of color, showing statistically no significant difference between the variables. $(\mathrm{p}>0.05)$.

\begin{tabular}{|c|c|c|c|c|c|}
\hline \multirow{2}{*}{ Qualification } & \multicolumn{3}{|c|}{ Which variable affects the perception of color, the most? } & \multirow{2}{*}{ P value } \\
\cline { 2 - 5 } & $\begin{array}{c}\text { Light } \\
\text { source }\end{array}$ & $\begin{array}{c}\text { Tooth, including } \\
\text { textures and layers }\end{array}$ & $\begin{array}{c}\text { Environ- } \\
\text { ment }\end{array}$ & Receiver(eye) & \multirow{2}{*}{0.49} \\
\hline MDS & 67 & 70 & 10 & 48 & \\
\hline BDS & 13 & 23 & 4 & 63 & \\
\hline Total & 80 & 93 & 14 & 63 & \\
\hline
\end{tabular}

Figure 3: Bar chart showing the association between qualification of the participants and responses for what variable affects the perception of color the most in shade selection. $X$ axis represents the variable affects the perception of color and $y$ axis represents the number of responses from the participants. The association between MDS(green) and BDS(red) among the different variables was found to be statistically insignificant with a Chi square value of 2.418 and $p$ value of $0.490(p>0.05$ ) (Chi square test)

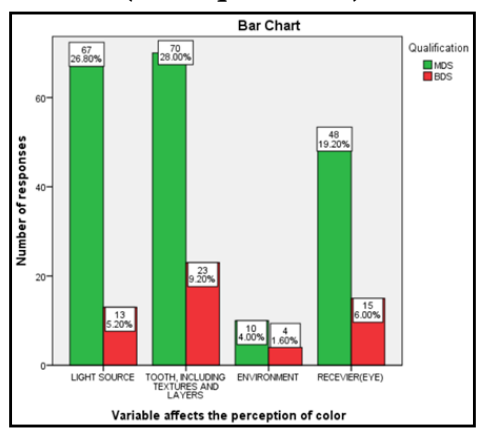

Table 5. shows the distribution of responses of participants on the ideal amount of light that is required for shade selection, showing statistically no significant difference between the variables. $(p>0.05)$.

\begin{tabular}{|c|c|c|c|c|c|}
\hline \multirow{2}{*}{ Qualification } & \multicolumn{4}{|c|}{$\begin{array}{c}\text { What is the ideal amount of light that is } \\
\text { required during shade selection? }\end{array}$} & \multirow{3}{*}{ P value } \\
\cline { 2 - 5 } & $\mathbf{1 0 0 0}$ lux & $\mathbf{1 5 0 0}$ lux & $\mathbf{2 0 0 0}$ lux & $\mathbf{2 5 0 0}$ lux & \\
\hline MDS & 21 & 80 & 79 & 15 & \multirow{2}{*}{0.236} \\
\hline BDS & 4 & 29 & 21 & 1 & \\
\hline Total & 25 & 109 & 100 & 16 & \\
\hline
\end{tabular}

Figure 4: Bar chart showing the association between qualification of the participants and responses for what is the ideal amount of light required during shade selection. $X$ axis represents the ideal amount of light that is required during shade selection and $y$ axis represents the number of responses from the participants. The association between MDS(green) and BDS(red) among the different variables was found to be statistically insignificant with a Chi square value of 4.243 and $p$ value of $0.236(\mathrm{p}>0.05)$.

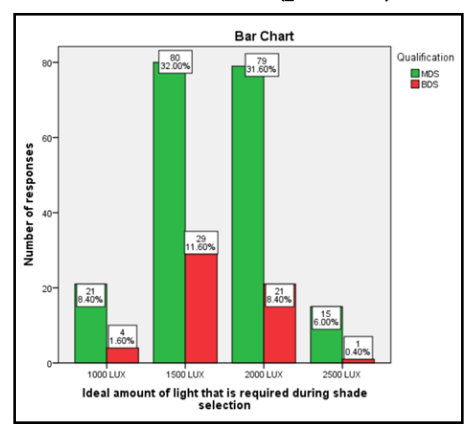

ing shade selection, Majority of the participants from MDS responded to yes $(71.20 \%)$, majority of the participants from BDS responded to yes $(16.80 \%)$. The association was analysed using Chi square test and was found to be statistically not significant. $(\mathrm{p}>0.05)$ (Table 11 and Figure 10).

\section{Discussion}

Our institution is passionate about high quality evidence based research and has excelled in various fields [42-52].

The present study has provided information on knowledge about the principle of tooth shade selection in dental students, practitioners and specialists. Color is one of the most important determinants of esthetic dentistry considering various factors such as type and intensity of the light source, time of day and year, patients clothes, age and gender [53]. Eye color, skin color and other factors usually influence and make it difficult during shade match- 
Table 6. Shows the distribution of responses of participants on the ideal time required for shade selection, showing statistically no significant difference between the variables. $(\mathrm{p}>0.05)$.

\begin{tabular}{|c|c|c|c|c|c|}
\hline \multirow{2}{*}{ Qualification } & \multicolumn{4}{|c|}{ What is the ideal time required for shade selection? } & \multirow{2}{*}{ P value } \\
\cline { 2 - 5 } & Within 5 seconds & $\mathbf{5 - 1 0}$ seconds & $\mathbf{1 0 - 1 5}$ seconds & $\mathbf{1 5 - 2 0}$ seconds & \\
\hline MDS & 73 & 101 & 16 & 5 & \multirow{2}{*}{0.43} \\
\hline BDS & 17 & 34 & 4 & 0 & \\
\hline Total & 90 & 135 & 20 & 5 & \\
\hline
\end{tabular}

Figure 5: Bar chart showing the association between qualification of the participants and responses for ideal time required for shade selection. $X$ axis represents the ideal time required for shade selection and $y$ axis represents the number of responses from the participants. The association between MDS(green) and BDS(red) among the different variables was found to be statistically insignificant with a Chi square value of 2.763 and $p$ value of $0.430(p>0.05)($ Chi square test).

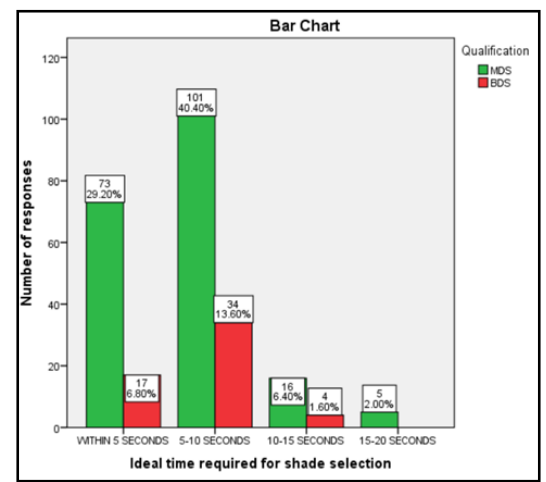

Table 7. shows the distribution of responses of participants on what they think on shade selection at the beginning of an appointment is better than doing it later, showing statistically significant difference between the variables. $(p<0.05)$.

\begin{tabular}{|c|c|c|c|c|}
\hline \multirow{2}{*}{ Qualification } & \multicolumn{3}{|l|}{$\begin{array}{l}\text { Do you think shade selection at the beginning } \\
\text { of an appointment is better than doing it later }\end{array}$} & \multirow{3}{*}{ P value } \\
\cline { 2 - 4 } & Yes & No & May be & \\
\hline MDS & 177 & 9 & 9 & \multirow{2}{*}{0.003} \\
\hline BDS & 42 & 10 & 3 & \\
\hline Total & 219 & 19 & 12 & \\
\hline
\end{tabular}

Figure 6: Bar chart showing the association between qualification of the participants and responses for what they think on shade selection at the beginning of an appointment is better than doing it later. $\mathrm{X}$ axis represents the shade selection at the beginning of an appointment is better than doing it later and $y$ axis represents the number of responses from the participants. The association between MDS(green) and BDS(red) among the different variables was found to be statistically significant with a Chi square value of 11.468 and $p$ value of $0.003(p<0.05)($ Chi square test).

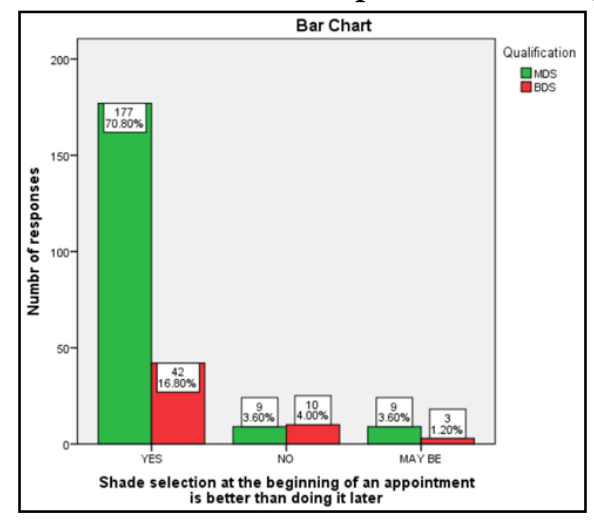

ing [54]. Even though light is one of the most important factors [55] it is the most commonly overlooked one. Furthermore, color imparted by different skin complexions is another factor that will have an effect on the shades of natural teeth $[56,57]$.

Among the questions that were asked, the majority of them told age, gender, appointment time and patient opinion plays an important role in shade selection. Tooth shade selection has been re- garded as a challenging procedure even for the experienced clinician. Like several previous studies, the present study also showed that the majority of the participants also used visual methods to perform the procedure even knowing the inaccuracies of this method [12, 58-60]. The deficiencies can be controlled by utilizing the instruments method, which provides an objective and scientifically accurate shade reading [26]. However, high tech gadgets such as colorimeters and spectrometers are expensive and difficult 
Table 8. shows the distribution of responses of participants on age and gender of the patients play an important role is shade selection, showing statistically significant difference between the variables. $(\mathrm{p}<0.05)$.

\begin{tabular}{|c|c|c|c|c|}
\hline \multirow{2}{*}{ Qualification } & \multicolumn{3}{|c|}{$\begin{array}{c}\text { Do you think the age and gender of the patients } \\
\text { play an important role in shade selection? }\end{array}$} & \multirow{3}{*}{ P value } \\
\cline { 2 - 4 } & Yes & No & May be & \\
\hline MDS & 184 & 7 & 4 & \multirow{2}{*}{0.001} \\
\hline BDS & 44 & 10 & 1 & \\
\hline Total & 228 & 17 & 5 & \\
\hline
\end{tabular}

Figure 7: Bar chart showing the association between qualification of the participants and responses for what they think on age and gender of patients play a role in shade selection, $X$ axis represents the age and gender of patients play an important role in shade selection and $y$ axis represents the number of responses from the participants. The association between MDS(green) and BDS(red) among the different variables was found to be statistically significant with a Chi square value of 14.633 and $p$ value of $0.001(p<0.05)($ Chi square test $)$.

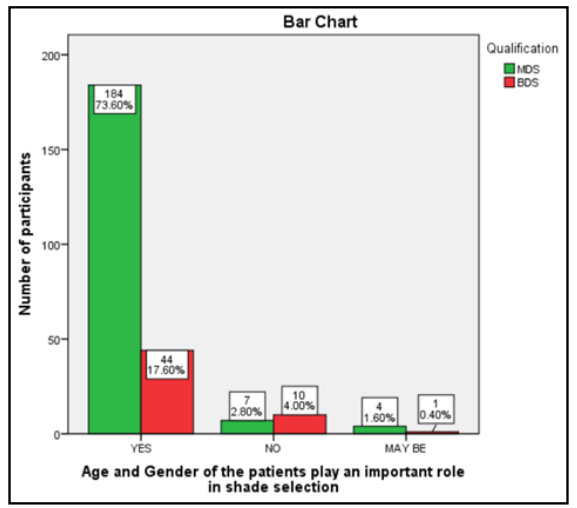

Table 9. Shows the distribution of responses of participants on Who according to you is more concerned about esthetics, showing statistically no significant difference between the variables. $(p>0.05)$.

\begin{tabular}{|c|c|c|c|c|}
\hline \multirow[t]{2}{*}{ Qualification } & \multicolumn{3}{|c|}{$\begin{array}{l}\text { Who according to you is more concerned about } \\
\text { esthetics? }\end{array}$} & \multirow[t]{2}{*}{$P$ value } \\
\hline & Young males & Young females & Older female & \\
\hline MDS & 12 & 180 & 3 & \multirow{3}{*}{0.089} \\
\hline BDS & 8 & 47 & 0 & \\
\hline Total & 20 & 227 & 3 & \\
\hline
\end{tabular}

Figure 8: Bar chart showing the association between qualification of the participants and responses for Who according to you is more concerned about esthetics, $X$ axis represents more concern about esthetics and $y$ axis represents the number of responses from the participants. The association between MDS(green) and BDS(red) among the different variables was

found to be statistically insignificant with a Chi square value of 4.844 and $p$ value of $0.089(p>0.05)(C h i$ square test).

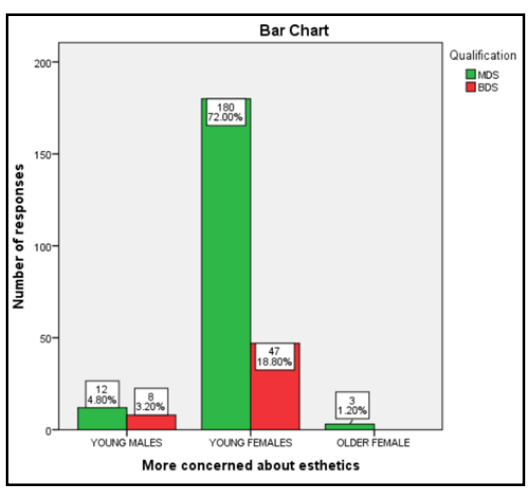

to operate in the clinical setting, the reason that the visual method remains the most commonly used for shade selection world wide [61].

Teeth tend to dry out towards the end of dental procedure or when rubber dam is applied. Therefore, it has been recommended to select shades prior tooth preparation [62]. This is especially true for porcelain fused to metal restorations. However, due to the requirement of preparation of a tooth colored die for the newer ceramic systems, shade has to be selected both before and after tooth preparation if all porcelain restorations are being planned. Northern daylight is considered a standard for judging 
Table 10. Shows the distribution of responses of participants on what is the most common complaint patients have regarding anterior teeth restoration, showing statistically no significant difference between the variables. $(p>0.05)$.

\begin{tabular}{|c|c|c|c|c|c|}
\hline \multirow{2}{*}{ Qualification } & \multicolumn{4}{|c|}{$\begin{array}{c}\text { In your opinion, what is the most common complaint patients have re- } \\
\text { garding anterior teeth restoration? }\end{array}$} & \multirow{2}{*}{ P value } \\
\cline { 2 - 5 } & Esthetic corrections & Fractured tooth & Dental caries & Failed restorations & \\
\hline MDS & 105 & 78 & 4 & 8 & \multirow{2}{*}{0.109} \\
\hline BDS & 38 & 17 & 0 & 0 & 8 \\
\hline Total & 143 & 95 & 4 & 8 & \\
\hline
\end{tabular}

Figure 9: Bar chart showing the association between qualification of the participants and responses for what is the most common complaint patients have regarding anterior teeth restoration, $\mathrm{X}$ axis represents most common complaint patients have regarding anterior teeth restoration and $y$ axis represents the number of responses from the participants. The association between MDS(green) and BDS(red) among the different variables was found to be statistically insignificant with a Chi square value of 6.061 and $p$ value of $0.109(p>0.05)($ Chi square test)

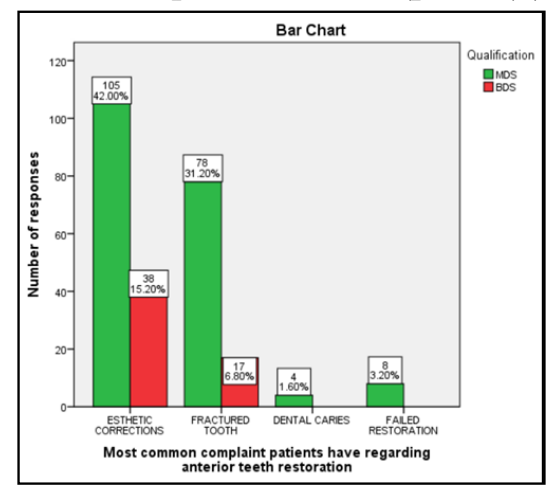

Table 11. Shows the distribution of responses of participants on whether they take patients' opinion while doing shade selection, showing statistically significant between the variables. $(p>0.05)$.

\begin{tabular}{|c|c|c|c|c|}
\hline \multirow{2}{*}{ Qualification } & \multicolumn{2}{|c|}{$\begin{array}{c}\text { Do you take patient's opinions } \\
\text { while doing shade selection ? }\end{array}$} & \multirow{2}{*}{ P value } \\
\cline { 2 - 4 } & Yes & No & Maybe & \\
\hline MDS & 178 & 9 & 8 & \multirow{2}{*}{0.006} \\
\hline BDS & 42 & 9 & 4 & \\
\hline Total & 220 & 18 & 12 & \\
\hline
\end{tabular}

Figure 10: Bar chart showing the association between qualification of the participants and responses for do they take patients' opinion during shade selection, $X$ axis represents patients' opinion during shade selection and $y$ axis represents the number of responses from the participants. Green color depicts responses from MDS and red color depicts responses from BDS. The association between MDS(green) and BDS(red) among the different variables was found to be statistically significant with Chi square value of 10.207 and a $p$ value of $0.006(p<0.05)($ Chi square test).

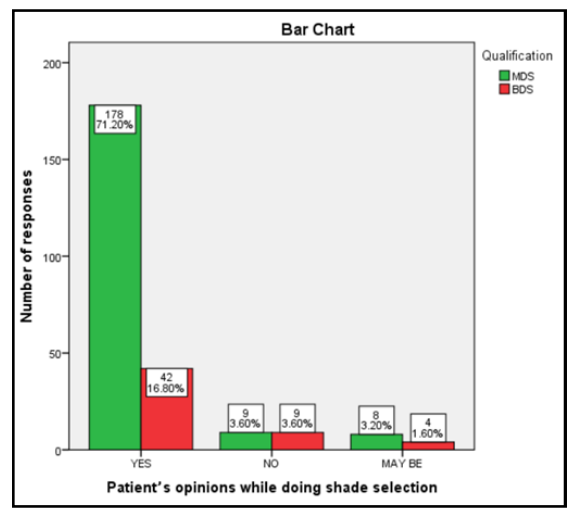

good light [63]. However, in everyday dental practice one cannot rely on sunlight for shade selection, hence color corrected fluorescent light with a CRI of 90 or above are recommended for dental operators $[64,65]$. The use of incandescent bulbs and dental unit lights is not recommended because of greater amount of yellow light emittance. Majority of the participants seemed to understand the importance of good lighting. Colored structures or surfaces around the such as adjacent teeth, gingival, lips, face skin, clothing of the patient and operative walls, can influence the perceived tooth color possibly through the phenomenon of 
contract [66-68]. Therefore, it has been recommended to ask the female patients to remove any lipstick before selecting a tooth shade.

Teeth should be cleaned of all debris and stains before shade selection is carried out. A significant difference was found in participants regarding shade selection. The center field of vision is regarded as most color sensitive and color perception because there is a large collection of color sensitive cones in the center of the retina, surrounded by rods which can perceive only brightness. For this reason, researchers have recommended viewing the patient at the eye level so that the central part of the retina is used in shade selection [69].

Wagenar et al, have stated that whenever an object such as a tooth is viewed for longer than 10 seconds, the color vision capability of the eyes decreases rapidly and the perceived color does not remain stable. In order to overcome any inaccuracies arising from eye fatigue, it has been recommended to get a second operator for the patient whenever shade selections are made [70, 71]. Most of the participants in the current study take 5-10 seconds for the shade selection. Teeth are known to possess a graduation of color from the cervical to the incisal area. According to Schwabacher et al and o' brien et al, 1994 the cervical color is modified by scattered light from the gingiva whereas the incisal color is most often translucent and is affected by its background [72]. Therefore, shade selected separately for different regions of the tooth surface and recorded on a shade distribution chart. The Vitapan classical shade guide is regarded as the most commonly used and known among the shade guides in dentistry, many other ceramic systems have been based on this guide $[73,74]$.

\section{Conclusion}

Shade determination is more rapidly evolving toward a more objective standard. The clinical importance of a proper shade selection in esthetic dentistry cannot be overlooked until an appropriate shade is selected, all other aspects of the restoration will not produce the best final result. Determining an accurate shade match is one of the most vital steps in esthetic restorative dentistry, it has always possessed a great challenge in esthetic dentistry. Dentists have little or no training in vision physiology or color science as comprehensive color training has continued to be a missing part in the dental school curriculum. In an era of growing interest in cosmetic dentistry, there is a need for adequate training and communication for better and more satisfactory results of shade matching. Based on the result obtained from the current study, we would like to conclude that more attention should be focused on improving the knowledge of color science and its application in esthetic dentistry as the color and appearance of teeth are a complex phenomenon, with many factors. Hence, for a good esthetic outcome to be achieved, the dentist should consider all possible entities which influence shade selection

\section{Limitations}

Within the limitations of this study, this cross sectional descriptive study shows a thorough knowledge and awareness among the specialists about shade selection and inadequate knowledge among general dentists. Therefore, establishing awareness among general dentists regarding shade selection for indirect veneers es- pecially for anterior teeth is compulsory.

\section{Future Scope}

This study can be conducted in a larger number of populations. The questions can be focused on the effect of resin cement on final shade, type of instruments for shade selection in future studies.

\section{Acknowledgement}

With Sincere gratitude, we acknowledge the staff members of the department of Conservative Dentistry and Endodontics, Saveetha Dental College and study participants for their extended support towards the completion of research.

\section{References}

[1]. Hall NR (1991) Tooth colour selection: the application of colour science to dental colour matching. Aust Prosthodont J 5:41-46

[2]. Yılmaz B, Irmak Ö, Yaman BC (2019) Outcomes of visual tooth shade selection performed by operators with different experience. J Esthet Restor Dent 31:500-507

[3]. Joiner A (2004) Tooth colour: a review of the literature. J Dent 32 Suppl $1: 3-12$

[4]. Hall NR (1991) Tooth colour selection: the application of colour science to dental colour matching. Aust Prosthodont J 5:41-46

[5]. Fondriest J (2003) Shade matching in restorative dentistry: the science and strategies. Int J Periodontics Restorative Dent 23:467-479

[6]. Khoo TSJ A comparison between a photographic shade analysis system and conventional visual shade matching method. https://doi.org/10.17077/etd. $\mathrm{q} 89 \mathrm{o} 1 \mathrm{c} 0 \mathrm{u}$

[7]. (2009) Shade matching. Dental Abstracts 54:244

[8]. Klemetti E, Matela A-M, Haag P, Kononen M (2006) Shade selection performed by novice dental professionals and colorimeter. J Oral Rehabil 33:31-35

[9]. Yılmaz B, Irmak Ö, Yaman BC (2019) Outcomes of visual tooth shade selection performed by operators with different experience. J Esthet Restor Dent 31:500-507

[10]. Klemetti E, Matela A-M, Haag P, Kononen M (2006) Shade selection performed by novice dental professionals and colorimeter. J Oral Rehabil 33:31-35

[11]. Hammad IA (2003) Inter Rater repeatability of shade selections with two shade guides. J Prosthet Dent 89:50-53

[12]. Judeh A, Al-Wahadni A (2009) A comparison between conventional visual and spectrophotometric methods for shade selection. Quintessence Int 40:e69-79

[13]. Alvin G (2007) Description of color, color-replication process, and esthetics. Contemporary fixed prosthodontics 4th ed New Delhi: Elsevier 709-739

[14]. Brewer JD, Wee A, Seghi R (2004) Advances in color matching. Dent Clin North Am 48:v, 341-58

[15]. Ahmad I (1999) Three-dimensional shade analysis: perspectives of color-Part I. Pract Periodontics Aesthet Dent 11:789-96; quiz 798

[16]. Okubo SR, Kanawati A, Richards MW, Childressd S (1998) Evaluation of visual and instrument shade matching. The Journal of Prosthetic Dentistry 80:642-648

[17]. Della Bona A, Barrett AA, Rosa V, Pinzetta C (2009) Visual and instrumental agreement in dental shade selection: three distinct observer populations and shade matching protocols. Dent Mater 25:276-281

[18]. Li Q, Wang YN (2007) Comparison of shade matching by visual observation and an intraoral dental colorimeter. Journal of Oral Rehabilitation 34:848-854

[19]. Carsten DL (2003) Successful shade matching--what does it take? Compend Contin Educ Dent 24:175-8, 180, 182 passim; quiz 188

[20]. Li Q, Wang YN (2007) Comparison of shade matching by visual observation and an intraoral dental colorimeter. Journal of Oral Rehabilitation 34:848-854

[21]. Hammad IA (2003) Inter Rater repeatability of shade selections with two shade guides. J Prosthet Dent 89:50-53

[22]. Salman A, Habib SR, Azad AA (2011) Scientific and artistic principles of tooth shade selection: a review. Pakistan Oral \& Dental Journal 31:

[23]. Jasinevicius TR, Curd FM, Schilling L, Sadan A (2009) Shade-matching 
abilities of dental laboratory technicians using a commercial light source. Journal of Prosthodontics: Implant, Esthetic and Reconstructive Dentistry 18:60-63

[24]. Al-Dosari AAF (2010) Reliability of tooth shade perception by dental professionals and patients. Pakistan oral \& dental journal 30

[25]. Paravina RD, Swift EJ Jr (2009) Color In Dentistry: Improving The Odds Of Correct Shade Selection. J Esthet Restor Dent 21:202-208

[26]. Stevenson B (2009) Current methods of shade matching in dentistry: a review of the supporting literature. Dent Update 36:270-2, 274-6

[27]. Govindaraju L, Gurunathan D (2017) Effectiveness of Chewable Tooth Brush in Children-A Prospective Clinical Study. J Clin Diagn Res 11:ZC31ZC34

[28]. Christabel A, Anantanarayanan P, Subash P, Soh CL, Ramanathan M, Muthusekhar MR, Narayanan V (2016) Comparison of pterygomaxillary dysjunction with tuberosity separation in isolated Le Fort I osteotomies: a prospective, multi-centre, triple-blind, randomized controlled trial. Int J Oral Maxillofac Surg 45:180-185

[29]. Soh CL, Narayanan V (2013) Quality of life assessment in patients with dentofacial deformity undergoing orthognathic surgery--a systematic review. Int J Oral Maxillofac Surg 42:974-980

[30]. Mehta M, Deeksha, Tewari D, et al (2019) Oligonucleotide therapy: An emerging focus area for drug delivery in chronic inflammatory respiratory diseases. Chem Biol Interact 308:206-215

[31]. Ezhilarasan D, Apoorva VS, Ashok Vardhan N (2019) Syzygium cumini extract induced reactive oxygen species-mediated apoptosis in human oral squamous carcinoma cells. J Oral Pathol Med 48:115-121

[32]. Campeau PM, Kasperaviciute D, Lu JT, et al (2014) The genetic basis of DOORS syndrome: an exome-sequencing study. Lancet Neurol 13:44-58

[33]. Kumar S, S S (2016) Knowledge and awareness regarding antibiotic prophylaxis for infective endocarditis among undergraduate dental students. Asian J Pharm Clin Res 154

[34]. Christabel SL (2015) Prevalence of type of Frenal Attachment and morphology of frenum in children, Chennai, Tamil Nadu. World J Dent 6:203-207

[35]. Kumar S, Rahman R (2017) Knowledge, awareness, and practices regarding biomedical waste management among undergraduate dental students. Asian J Pharm Clin Res 10:341

[36]. Sridharan G, Ramani P, Patankar S (2017) Serum metabolomics in oral leukoplakia and oral squamous cell carcinoma. J Cancer Res Ther 13:556-561

[37]. Ramesh A, Varghese SS, Doraiswamy JN, Malaiappan S (2016) Herbs as an antioxidant arsenal for periodontal diseases. J Intercult Ethnopharmacol 5:92-96

[38]. Thamaraiselvan M, Elavarasu S, Thangakumaran S, Gadagi JS, Arthie T (2015) Comparative clinical evaluation of coronally advanced flap with or without platelet rich fibrin membrane in the treatment of isolated gingival recession. J Indian Soc Periodontol 19:66-71

[39]. Thangaraj SV, Shyamsundar V, Krishnamurthy A, Ramani P, Ganesan K, Muthuswami M, Ramshankar V (2016) Molecular Portrait of Oral Tongue Squamous Cell Carcinoma Shown by Integrative Meta-Analysis of Expression Profiles with Validations. PLoS One 11:e0156582

[40]. Ponnulakshmi R, Shyamaladevi B, Vijayalakshmi P, Selvaraj J (2019) In silico and in vivo analysis to identify the antidiabetic activity of beta sitosterol in adipose tissue of high fat diet and sucrose induced type-2 diabetic experimental rats. Toxicol Mech Methods 29:276-290

[41]. (2018) Fluoride, fluoridated toothpaste efficacy and its safety in children review. Int J Pharm Res. https://doi.org/10.31838/ijpr/2018.10.04.017

[42]. Vijayashree Priyadharsini J (2019) In silico validation of the non-antibiotic drugs acetaminophen and ibuprofen as antibacterial agents against red complex pathogens. J Periodontol 90:1441-1448

[43]. Pc J, Marimuthu T, Devadoss P (2018) Prevalence and measurement of anterior loop of the mandibular canal using CBCT: A cross sectional study. Clin. Implant Dent. Relat. Res.

[44]. Ramesh A, Varghese S, Jayakumar ND, Malaiappan S (2018) Comparative estimation of sulfiredoxin levels between chronic periodontitis and healthy patients - A case-control study. J Periodontol 89:1241-1248

[45]. Ramadurai N, Gurunathan D, Samuel AV, Subramanian E, Rodrigues SJL (2019) Effectiveness of $2 \%$ Articaine as an anesthetic agent in children: randomized controlled trial. Clin Oral Investig 23:3543-3550

[46]. Sridharan G, Ramani P, Patankar S, Vijayaraghavan R (2019) Evaluation of salivary metabolomics in oral leukoplakia and oral squamous cell carcinoma. J Oral Pathol Med 48:299-306

[47]. Ezhilarasan D, Apoorva VS, Ashok Vardhan N (2019) Syzygium cumini extract induced reactive oxygen species-mediated apoptosis in human oral squamous carcinoma cells. J Oral Pathol Med 48:115-121
[48]. Mathew MG, Samuel SR, Soni AJ, Roopa KB (2020) Evaluation of adhesion of Streptococcus mutans, plaque accumulation on zirconia and stainless steel crowns, and surrounding gingival inflammation in primary molars: Randomized controlled trial. Clin Oral Investig 1-6

[49]. Samuel SR (2021) Can 5-year-olds sensibly self-report the impact of developmental enamel defects on their quality of life? Int J Paediatr Dent 31:285-286

[50]. R H, Hannah R, Ramani P, Ramanathan A, R JM, Gheena S, Ramasubramanian A, Monika K (2020) CYP2 C9 polymorphism among patients with oral squamous cell carcinoma and its role in altering the metabolism of benzo[a]pyrene. Oral Surgery, Oral Medicine, Oral Pathology and Oral Radiology 130:306-312

[51]. Chandrasekar R, Chandrasekhar S, Sundari KKS, Ravi P (2020) Development and validation of a formula for objective assessment of cervical vertebral bone age. Prog Orthod 21:38

[52]. Vijayashree Priyadharsini J, Smiline Girija AS, Paramasivam A (2018) In silico analysis of virulence genes in an emerging dental pathogen A. baumannii and related species. Arch Oral Biol 94:93-98

[53]. Marcucci B (2003) A shade selection technique. J Prosthet Dent 89:518-521

[54]. Paul S, Peter A, Pietrobon N, Hämmerle CHF (2002) Visual and spectrophotometric shade analysis of human teeth. J Dent Res 81:578-582

[55]. Dagg H, O’Connell B, Claffey N, Byrne D, Gorman C (2004) The influence of some different factors on the accuracy of shade selection. Journal of Oral Rehabilitation 31:900-904

[56]. Jahangiri L, Reinhardt SB, Mehra RV, Matheson PB (2002) Relationship between tooth shade value and skin color: An observational study. The Journal of Prosthetic Dentistry 87:149-152

[57]. Rosenstiel SF, Land MF, Fujimoto J (2001) Contemporary Fixed Prosthodontics. Year Book Medical Pub

[58]. Hall NR (1991) Tooth colour selection: the application of colour science to dental colour matching. Aust Prosthodont J 5:41-46

[59]. Della Bona A, Barrett AA, Rosa V, Pinzetta C (2009) Visual and instrumental agreement in dental shade selection: three distinct observer populations and shade matching protocols. Dent Mater 25:276-281

[60]. Li Q, Wang YN (2007) Comparison of shade matching by visual observation and an intraoral dental colorimeter. Journal of Oral Rehabilitation 34:848-854

[61]. Paravina RD (2002) Evaluation of a newly developed visual shade-matching apparatus. Int J Prosthodont 15:528-534

[62]. Paravina RD (2002) Evaluation of a newly developed visual shade-matching apparatus. Int J Prosthodont 15:528-534

[63]. Barna GJ, Taylor JW, King GE, Pelleu GB (1981) The influence of selected light intensities on color perception within the color range of natural teeth. The Journal of Prosthetic Dentistry 46:450-453

[64]. Nallaswamy D (2017) Textbook of Prosthodontics. JP Medical Ltd

[65]. Kruschwitz JD Color Rendering Index. Field Guide to Colorimetry and Fundamental Color Modeling. https://doi.org/10.1117/3.2500912.ch30

[66]. Habib SR (2012) AWARENESS OF TOOTH SHADE SELECTION PRINCIPLES AMONG DENTAL STUDENTS, INTERNS, GENRAL DENTISTS AND SPECIALISTS. Pakistan Oral \& Dental Journal 32:

[67]. Jahangiri L, Reinhardt SB, Mehra RV, Matheson PB (2002) Relationship between tooth shade value and skin color: An observational study. The Journal of Prosthetic Dentistry 87:149-152

[68]. Susanty H, Gita F, Kusdhany LS, Marito P (2018) Relationship between the color of the maxillary central incisors and age, sex, and skin color: value analysis using a spectrophotometer. Journal of Physics: Conference Series 1073:042009

69]. Fenton AH (2004) Selecting and arranging prosthetic teeth and occlusion for the edentulous patient. Eckert Jacob Fenton AH Mericske-Stern, editors Prosthodontic treatment for edentulous patients 12th ed St Louis: Mosby 310

[70]. Chu SJ (2002) Precision shade technology: contemporary strategies in shade selection. Pract Proced Aesthet Dent 14:79-83; quiz 84

[71]. Burkinshaw SM (2004) Colour in relation to dentistry. Fundamentals of colour science. Br Dent J 196:33-41; discussion 29

[72]. Schwabacher WB, Goodkind RJ, Lua MJR (1994) Interdependence of the Hue, Value, and Chroma in the Middle Site of Anterior Human Teeth. Journal of Prosthodontics 3:188-192

[73]. Analoui M, Papkosta E, Cochran M, Matis B (2004) Designing visually optimal shade guides. J Prosthet Dent 92:371-376

[74]. Montero J, Gómez-Polo C (2016) Effect of ceramic thickness and cement shade on the final shade after bonding using the 3D master system: a laboratory study. Clinical and Experimental Dental Research 2:57-64 